
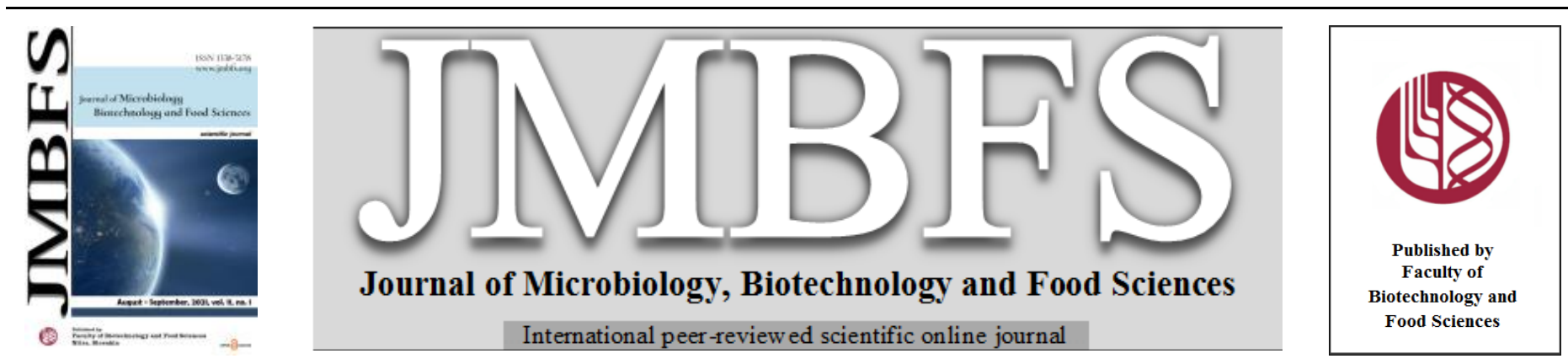

\title{
APPLICATION OF METHYLIGHT APPROACH FOR DETECTION OF CYTOSINE METHYLATION IN FLAX SEEDS GROWN NEAR CHERNOBYL
}

\author{
Veronika Lancíková ${ }^{* 1}$, Jana Žiarovská
}

\section{Address(es):}

${ }^{1}$ Institute of Plant Genetics and Biotechnology, Plant Science and Biodiversity Center, Slovak Academy of Sciences, Nitra, Slovakia.

${ }^{2}$ Department of Genetics and Plant Breeding, Faculty of Agrobiology and Food Resources, Slovak University of Agriculture, Nitra, Slovakia.

*Corresponding author: veronika.lancikova@savba.sk

\section{ARTICLE INFO}

Received 13. 12. 2019

Revised 17.3. 2021

Accepted 18.3. 2021

Published 1. 8. 2021

Regular article

OPEN OACCESS $_{\text {A }}$

\section{ABSTRACT}

Nowadays, various approaches for the precise DNA methylation analysis are known. This study applied an advanced MethyLight approach for precise detection of cytosine methylation. Chernobyl area is still contaminated by long-lived radioisotopes thus the potential risk of DNA damage by radiation remains relatively high. Plants as sessile organisms are directly affected by irradiation. For the analysis presented herein, flax seeds grown on the experimental fields near Chernobyl have been used. Cytosine methylation was quantified in the specific coding region of Fatty acid desaturase 3A gene which has an important function in fatty acid biosynthesis. Quantitative real-time MethyLight revealed fully methylated sequence in the targeted gene.

Keywords: MethyLight, radioactivity, FAD3A, cytosine methylation, quantification

\section{INTRODUCTION}

When a methyl group binds to a cytosine base, and forms 5-methylcytosine, this process is called DNA methylation, and is an important epigenetic trait involved in various biological processes (He $\boldsymbol{e t}$ al., 2011). For proper understanding of epigenetic changes, it is crucial to know the exact location of 5-methylcytosine in the genome. Dynamic changes in DNA methylation during the plant development and stress response are characteristic for promoter region and gene sequences as well (Suzuki and Bird, 2008). Development of the bisulfite modification of genomic DNA represents an important step in expansion of new methodologies in DNA methylation analysis. Bisulfite modification means the DNA alteration where the unmethylated cytosines are converted to uracil while methylated cytosines are detected as unchanged. This modification allows subsequent analysis of PCR products to differentiate methylated and unmethylated cytosines in DNA sequence. Multiple approaches for DNA methylation analysis at the specific locus are based on the bisulfite modification (Clark et al., 2006, Shen and Waterland, 2007).

Analysis of the methylated cytosines in DNA sequence requires the application of relatively cost- and time-consuming techniques. DNA methylation is not transferred during the PCR reaction, therefore the methods for DNA methylation analysis are generally based on modification of genomic DNA using sodium bisulfite (Eads et al., 2000). Initial methods for DNA methylation analysis such as restriction analysis using methylation sensitive enzymes followed by Southern blotting have been replaced with the more advanced approaches in which the genomic DNA is modified using sodium bisulfite. The main reason to develop more reliable and efficient methods for methylation detection was the occurence of false positive results due to the incomplete restriction digestion and the need of DNA characterized by high concentration and quality (Singer $\boldsymbol{e t}$ al., 1990, Eads et al., 2000).

Eads et al. (2000) published a quantitative approach for identification of DNA methylation, so-called MethyLight. The method measures fluorescence real time while combines PCR method and fluorescently labeled TaqMan probes (Eads $\boldsymbol{e}$ al., 2000, Trinh et al., 2001, Olkhov-Mitsel et al., 2014). The MethyLight allows the quantification of methylation at the particular locus in the genome and uses specifically designed oligonucleotides that hybridize to bisulfite modified DNA based on the methylation status in original genomic DNA (Olkhov-Mitsel et al., 2014). The MethyLight is highly sensitive method which allows the detection of methylated alleles even in the presence of a 10000 more unmethylated alleles. This quantitative analysis makes it possible to precisely determine the occurence of a particular type of DNA methylation (Eads et al., 2000, Hernández et al., 2013). The essential parameters to develop the
MethyLight approach are primer and probe design, appropriate selection of fluorescent dye and the optimization of reaction conditions (Olkhov-Mitsel $\boldsymbol{e}$ al., 2014). Currently, this innovative approach is considered as ideal particularly in clinical research because of the very precise identification of methylated cytosines (Zhou et al., 2011).

Redshaw et al. (2014) compared various approaches for DNA methylation analysis: a) MethyLight using quantitative real-time PCR, b) MethyLight using digital PCR, c) restriction digestion using methylation sensitive enzymes followed by quantitative PCR, d) restriction digestion using methylation sensitive enzymes followed by digital PCR and e) PCR amplification of genomic DNA modified using sodium bisulfite with subsequent sequencing of PCR product. The results obtained by MethyLight approach showed more accurate quantification in comparison to the restriction digestion using methylation sensitive enzymes. On the other hand, MethyLight is limited to the analysis of CG dinucleotides which are present in the sequence amplified by specific primers.

The aim of the presented study was to apply the MethyLight protocol for quantification of cytosine methylation in the specific gene region. Herein presented study is a part of multi-year investigation of plant adaptation in the radioactive Chernobyl area. In the beginning, two experimental plots have been established near Chernobyl and crops of agricultural importance have been chosen for investigation, e.g. flax, soybean, sunflower, wheat. The majority of experiments have been performed on flax genome and proteome. Thus, flax seeds grown on the experimental fields around Chernobyl were used for analysis. Previous analysis revealed the presence of numerous DNA methylation sites in the genes encoding the fatty acid biosynthesis using the bisulfite sequencing method (Lancikova et al., 2020). Therefore, the MethyLight approach was tested to assess the cytosine methylation in the specific exonic region of Fatty acid desaturase $3 \mathrm{~A}(F A D 3 \mathrm{~A})$ gene which is involved in biosynthesis of alphalinolenic acid. The applied MethyLight protocol accurately quantified the present methylation without the need of DNA sequencing.

\section{MATERIAL AND METHODS}

Experimental plots and flax seed material

Two experimental plots, remediated (non-radioactive) and radioactive has been established in the close proximity of Chernobyl in 2007. Flax (Linum usitatissimum L.) of Kyivskyi genotype has been cultivated on the experimental plots. Flax seeds for the presented study had been harvested in 2013, after six subsequent years of growing near Chernobyl. Flax seeds had been harvested 
from both plots in three biological replicates. Radioactively contaminated plot has been located approximately $5 \mathrm{~km}$ from Chernobyl Nuclear Power Plant (CNPP), near the village Chistogalovka and soil radioactivity $20650 \pm 1050$ $\mathrm{Bq} \cdot \mathrm{kg}^{-1}$ of ${ }^{137} \mathrm{Cs}$, and $5180 \pm 550 \mathrm{~Bq} \cdot \mathrm{kg}^{-1}$ of ${ }^{90} \mathrm{Sr}$ has been determined. Remediated field has been located directly in the Chernobyl town and soi radioactivity $1414 \pm 71 \mathrm{~Bq} \cdot \mathrm{kg}^{-1}$ of ${ }^{137} \mathrm{Cs}$ and $550 \pm 55 \mathrm{~Bq} \cdot \mathrm{kg}^{-1}$ has been estimated In both experimental plots, contents of aleurite (silt) and pelitic soil ranges from 20 to $30 \%$. The soils contained $12 \%$ clay, $2 \%$ organic material, and have been characterized as sod-podzolic with a loamy-sand texture, which is derived from sandy fluvio-glacial deposits. Soil $\mathrm{pH}$ of remediated plot was 6.6 , and $\mathrm{pH}$ of radioactively contaminated plot 5.6. The soil electric conductivity for both plots was $0.20 \mathrm{dS} . \mathrm{m}^{-1}$ (Lancíková and Žiarovská, 2020).

\section{DNA extraction}

Genomic DNA has been extracted according the method by Rogers and Bendich (1994). Mature flax seeds, $0.5 \mathrm{~g}$ (approximately 100 seeds), have been grinded to a fine powder in liquid nitrogen. Extraction solution $(50 \%(\mathrm{v} / \mathrm{v})$ phenol, $0.45 \mathrm{M}$ sucrose, 5mM EDTA, $0.2 \%$ (v/v) 2-mercaptoethanol, $50 \mathrm{mM}$ Tris-HCL, pH 8.8) has been added to the flax seed powder and shaken for $30 \mathrm{~min}$ at $4{ }^{\circ} \mathrm{C}$. Then, the samples have been centrifuged at $10000 \mathrm{rpm}$ for $10 \mathrm{~min}$ at $4{ }^{\circ} \mathrm{C}$, and the aquatic phase has been transferred into a new tube. The one volume of phenolchloroform-isoamylalcohol solution $(25: 24: 1)$ was added to aquatic phase, and mixed vigorously, then centrifuged at $9500 \mathrm{~g}$ for $15 \mathrm{~min}$ at $4{ }^{\circ} \mathrm{C}$. Extraction using phenol-chloroform has been repeated until clear aquatic phase without brown blur. Isopropanol DNA precipitation has been carried out, then the samples has been incubated at room temperature for $20 \mathrm{~min}$, and centrifuged at $5000 \mathrm{~g}$ for 5 min. Final washing step has been performed using 70\% ethanol. DNA pellet has been dissolved in $300 \mu \mathrm{l}$ TE buffer $(\mathrm{pH} 8,10 \mathrm{mM}$ Tris, 1mM EDTA) (Lancíková and Žiarovská, 2020).

\section{Sodium bisulfite modification of genomic DNA}

For DNA modification using sodium bisulfite, $100 \mathrm{ng}$ of genomic DNA has been treated with sodium bisulfite using the EpiTect Bisulfite Kit (Qiagen) according the manufacturer's instruction. DNA modification protocol has been optimized for low concentration samples, approximately 1 - $500 \mathrm{ng}$ of DNA in a maximum reaction volume of $40 \mu \mathrm{l}$ has been used. Reaction conditions consisted of a $5 \mathrm{~min}$ $95^{\circ} \mathrm{C}$ denaturation, $25 \min 60^{\circ} \mathrm{C}$ incubation, 5 min $95^{\circ} \mathrm{C}$ denaturation, $85 \mathrm{~min}$ $60{ }^{\circ} \mathrm{C}$ incubation, $5 \min 95^{\circ} \mathrm{C}$ denaturation, $175 \min 60^{\circ} \mathrm{C}$ incubation, and cooling at $20^{\circ} \mathrm{C}$. DNA degradation has been caused by sodium bisulfite treatment. Therefore, DNA amount has been significantly reduced after treatment, resulting in average yield 20-30 ng of single stranded DNA (ssDNA) (Lancíková et al., 2020).

\section{Primers and probe design}

Quantitative MethyLight approach has been developed for methylation analysis in the particular coding sequence $\left(107 \mathrm{bp}, 5^{\text {th }}\right.$ exon, $\left.3270-3617 \mathrm{bp}\right)$ of Fatty acid desaturase 3A (FAD3A) gene. Primers for PCR amplification of desired gene region were designed as follows: forward primer 5' TAGAGGTAAAGAGTGGAGTTATTTA-3' and reverse primer 5' AATAAATAACATAAATACCAATATCATAAT-3'. Two fluorescently labeled probes were designed for both variants, methylated and unmethylated gene sequence. The probe sequence for methylated gene region was 5' CGTGGAGGGTTGACGATCGTCGATCGAGATTACG-3' and was labeled at the 5' end using 6-carboxyfluorescein (FAM, maximum absorbance $494 \mathrm{~nm}$, maximum emission $518 \mathrm{~nm}$ ) and at the $3^{\prime}$ end using 5carboxytetramethylrhodamine (TAMRA, maximum absorbance $555 \mathrm{~nm}$, maximum emission $580 \mathrm{~nm}$ ). The probe sequence for unmethylated variant of gene region was $5^{\prime}$-TGTGGAGGGTTGATGATTGTTGATTGAGATTATG-3 and was labeled at the $5^{\prime}$ end using Yakima Yellow (analog of $\mathrm{VIC}^{\mathrm{TM}}$, maximum absorbance $530 \mathrm{~nm}$, maximum emission $549 \mathrm{~nm}$ ), at the 3' end using Black Hole Quencher 1 (BHQ1, maximum absorbance $534 \mathrm{~nm}$, maximum emission $549 \mathrm{~nm}$ ) (Haushalter, 2008). The position of primers and probes within the gene region of interest is shown in the Fig. 1.

\section{Quantitative real-time MethyLight PCR and high resolution melting analysis}

Firstly, the positive control (reference sample artificially methylated) has been prepared by CG methyltransferase (M.SssI), (New England BioLabs Inc. Ipswich, MA, USA), and the negative control (reference sample with unmethylated status) was the PCR product of the selected coding region. PCR amplification and subsequent high resolution melting analysis (HRM) has been carried out in a LightCycler ${ }^{\circledR}$ Nano (Roche Applied Sciences, Penzberg, Upper Bavaria, Germany) (Lancíková et al., 2020). Genomic DNA modified by sodium bisulfite was amplified in quantitative real-time MethyLight PCR, the reaction mixture contained $2 \times$ Maxima Hot Start PCR Master Mix $(2 \times$ Hot Start PCR Buffer, Maxima Hot Start Taq DNA polymerase, 0,4 mM of each dNTP, $4 \mathrm{mM}$
$\mathrm{MgCl}_{2}$ ), $900 \mathrm{nM}$ of forward and reverse primer, $300 \mathrm{nM}$ of fluorescently labeled probes and $50 \mathrm{ng}$ of modified genomic DNA. The PCR reactions consisted of initial denaturation at $95^{\circ} \mathrm{C}$ for $10 \mathrm{~min}$, then 45 cycles of denaturation at $95^{\circ} \mathrm{C}$ fo $15 \mathrm{sec}$ and primer annealing at $55^{\circ} \mathrm{C}$ for $1 \mathrm{~min}$, polymerization step was omitted High resolution melting analysis has been performed with temperature ramping from 60 to $97^{\circ} \mathrm{C}$ at a $0.05^{\circ} \mathrm{C} \mathrm{s}^{-1}$ rate (Lancíková et al., 2020). The melting temperature of methylated and unmethylated PCR products was determined. The LightCycler ${ }^{\circledR}$ Nano Software 1.1 was used for data analysis. The reactions were performed in biological triplicates (Lancíková et al., 2020).

a)

3640

TACGAGCAGAAGCTGC CGTGG TA CAGAGGCAAAGAGTGGAGCTACCTAC GTGGAGGGCTGA CGACCETCG ATCGAGATTA CEGGGTCATCAACA AC ATCACCATGACATTGGCACCCATGTTATTCACCA TC TCTTCCC TCAAATG CCA CA CTATCACCTAG TCGAAG GGTAAGG GG TCTTGAT TA TTAACTTAATG TTTTGTTGT 3747

b) 3640

TACGAGCAGARGCTGCCGTGGTACAGAGGCAAAGAGTGGAGCTACCTATGTGGAGGGCTGATGACTGTTC ATTEA GATTA TGGGGTCATCAACAACA TCCACCATGACATTGGCACCCATGTTATTCACCATCTCTTCCC TCAAATGCCACACTATCACCTAGTCGAAGGGTAAGGAGTCTTGATTATTAACTTAATGTTTTTGTTGI

3747

Figure 1 DNA sequence of FAD3A gene coding region (3640-3747 bp). Blue color - forward and reverse primers for PCR amplification of targeted region yellow color - probe sequences; green color - targeted dinucleotides CG analysed for the presence or absence of methylated cytosine; a) the probe specifically designed for methylated gene sequence; b) the probe specifically designed for unmethylated gene sequence;

\section{RESULTS AND DISCUSSION}

Flax seeds grown on the experimental plots near Chernobyl have been investigated for the presence of methylated cytosines using the quantitative realtime MethyLight approach. During the previous investigations, the presence of methylated cytosines has been identified in the flax genes involved in fatty acid biosynthesis pathway, therefore coding sequence of Fatty acid desaturase 3A gene $\left(5^{\text {th }}\right.$ exon, gene position $3270-3617 \mathrm{bp}$ ) has been further investigated. Cytosine methylation is a frequent epigenetic modification closely related to the environmental stress. In many cases, DNA methylation can protect the plant genome from further damage caused by stress factor. Epigenetic mechanisms such as DNA methylation can involve alterations in gene expression, changes in chromatin structure and generation of new phenotypes. Moreover, methylation can enhance the plant adaptability to environmental changes and contribute to the generation of stress-resistant phenotype (Thiebaut $\boldsymbol{e t}$ al., 2019). Specifically, FAD3A gene methylation can affect the mechanism of de novo fatty acid biosynthesis whereas the gene plays a crucial role in the conversion of linoleic acid to alpha-linolenic acid. In result, this may lower the quality of flaxseed oil. This study was oriented to provide a new methodology for plant DNA methylation research and aimed to test a precise protocol for methylation quantification using the advanced MethyLight method.

The certain level of radioactivity is still present in the Chernobyl area which causes serious damage at the genomic level frequently represented by DNA methylation. Therefore, seeds collected from the experimental plots around Chernobyl have been used for analysis. Various techniques are known for identification of DNA methylation. However, here presented real-time quantitative MethyLight approach belongs among the most advanced, straightforward and accurate methods. Aforementioned approach is well established in clinical research and diagnostics even though there are still a little studies dealing with MethyLight in plant sciences.

Herein, fluorescently labeled probes were specifically designed for methylated and unmethylated variants of targeted gene sequence. DNA samples extracted from flax seeds harvested from two experimental fields, remediated (nonradioactive) and radioactive, were investigated in biological triplicate. The obtained amplification profiles were compared against known methylated and unmethylated standards to accurately quantify the cytosine methylation. Results showed that targeted gene sequence is fully methylated, at the level $100 \%$ methylation, for both variants of flax seeds collected from remediated and radioactively contaminated experimental plots. The amplification profiles for target samples, methylated and unmethylated standards are shown in the Fig. 2. As shown in the fig. 2, target samples correspond to the methylated standard, therefore the complete cytosine methylation in the investigated gene region can be concluded. 

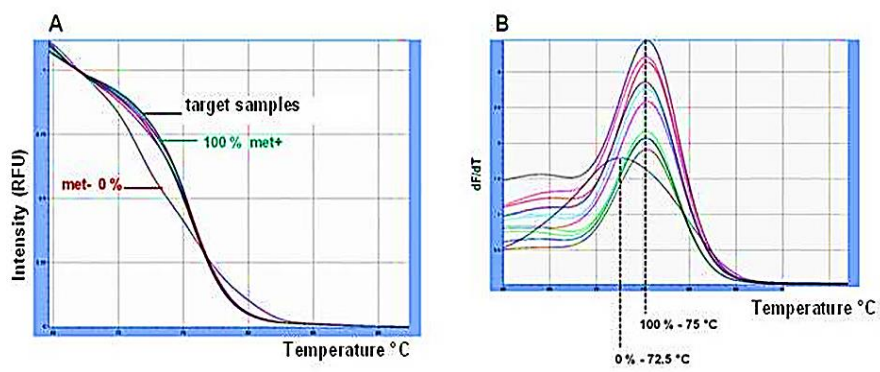

Figure 2 The quantification of cytosine methylation level in the coding sequence of FAD3A gene using the MethyLight approach. Cytosine methylation in target samples was estimated in comparison to the known methylated and unmethylated standards. A the amplification profiles of target samples, methylated (100\% met+) and unmethylated (0\% met-) standards are shown, target samples correspond to the $100 \%$ methylated standard; B HRM analysis of target samples, positive (methylated) and negative (unmethylated) standards, unmethylated standard melted at the $72.5^{\circ} \mathrm{C}$, methylated standard and target samples melted at the $75^{\circ} \mathrm{C}$;

Several authors have been previously highlighted the most important advantages of MethyLight approach in DNA methylation detection such as the workflow simplicity, multiple samples can be analyzed simultaneously, high sensitivity and efficiency. For instance, this approache requires only low concentration of genomic DNA, there is no need of post-PCR manipulation such as ge electrophoresis which reduces the risk of contamination. On the other side, MethyLight is no able to assess cytosine methylation at the single nucleotide, however provides an comprehensive information about the methylation level in specific gene loci (Eads et al., 2000, Ogino et al., 2006, Zhang et al., 2010, Liu et al., 2016). For that reason, the approach such as bisulfite sequencing might be better option for assessment of individual cytosine methylation, however for overall DNA methylation quantification in targeted short gene region, quantitative MethyLight might be a method of choice. The method is the mos commonly applied in clinical diagnostics, DNA methylation identification in multiple candidate sequences, assessment of DNA polymorphism, absolute quantification of infrequent DNA methylation using MethyLight droplet digita PCR, gene expression analysis due to the application of fluorescently labeled probes or analysis of repetitive elements (Weisenberger $\boldsymbol{e t}$ al., 2005, Zhang $\boldsymbol{e}$ al., 2010, Endo et al., 2015, Yu et al., 2015).

\section{CONCLUSION}

In this study, the sensitivity and accuracy of quantitative real-time MethyLigh approach for identification of cytosine methylation in flax seeds harvested from Chernobyl area has been tested. Coding sequence of the specific gene, FAD3A has been investigated for the presence of DNA methylation. The presence of identified cytosine methylations in FAD3A gene might be closely related to the changes in content of alpha-linolenic acid in flax seeds. Therefore, the assessment of accurate method for methylation detection is of great importance. It might be concluded that MethyLight approach is highly suitable for identification of DNA methylation in the particular gene region. It provides reliable and fast results without the need of post-PCR analysis such as gel electrophoresis or sequencing.

Acknowledgments: This work was co-funded by the COST CA19125 Epigenetic mechanisms of Crop Adaptation To Climate cHange (EPI-CATCH) and Research Centre AgroBioTech built in the framework of European Community project Building Research Centre "AgroBioTech" ITMS 26220220180. The authors thank to Dr. Martin Hajduch for project coordination, prof. Namik M Rashydov for coordination of experimental fields and sample collection, Mrs. Valentyna V. Berezhna and Mr. Volodymyr Sakada for technical help with maintenance of the Chernobyl fields.

\section{REFERENCES}

CLARK, J. S., STATHAM, A., STIRZAKER, C., MOLLOY, L. P., FROMMER, M. (2006). DNA methylation: Bisulfite modification and analysis. Nature Protocols, 1, 2353-2364. http://dx.doi.org/10.1038/nprot.2006.324

EADS, C. A., DANENBERG, K. D., KAWAKAMI, K., SALTZ, L. B., BLAKE C., SHIBATA, D., DANENBERG, P. V., LAIRD, P. W. (2000). MethyLight: a high-throughput assay to measure DNA methylation. Nucleic Acids Research, 28(8), e.32. http://dx.doi.org/10.1093/nar/28.8.e32

ENDO, K., LI, J., NAKANISHI, M., ASADA, T., IKESUE, M., GOTO, Y.

FUKUSHIMA, Y., IWAI, N. (2015). Establishment of the MethyLight Assay for Assessing Aging, Cigarette Smoking and Alcohol Consumption. BioMed Research International. http://dx.doi.org/10.1155/2015/451981

HAUSHALTER, K.A. (2008). Labeling DNA and Preparing Probes. Current

Protocols, 00(1):8.4.1-8.4.22. https://doi.org/10.1002/9780470089941.et0804s00

HE, X. J., CHEN, T., ZHU, J. K. (2011). Regulation and function of DNA methylation in plants and animals. Cell Research, 21, 442-465. http://dx.doi.org/10.1038/cr.2011.23

HERNÁNDEZ, H. G., YAT TSE, M., PANG, S. C., ARBOLEDA, H. FORERO, D. A. (2013). Optimizing methodologies for PCR-based DNA methylation analysis. Biotechniques, 55(4),

181-197. http://dx.doi.org/10.2144/000114087

LANCÍKOVÁ, V., JOPČÍK, M., ŽIAROVSKÁ, J. (2020) Fatty acid desaturase 3A gene-specific DNA methylation patterns in flax seeds harvested from a radioactive area near Chernobyl. Plant Gene, 24:100254. http://dx.doi.org/10.1016/j.plgene.2020.100254

LANCÍKOVÁ, V., ŽIAROVSKÁ, J. (2020) Evaluation of the Fatty Acid Desaturase 3A Genes Stability in Flax Seeds Harvested from Radio-contaminated Area near Chernobyl. Journal of Microbiology, Biotechnology and Food Sciences, 9(4), 816-819. http://dx.doi.org/ 10.15414/jmbfs.2020.9.4.816-819

LIU, Z., ZHOU, J., GU, L., DENG, D. (2016). Significant impact of amount PCR input templates on various PCR-based DNA methylation analysis and countermeasure. Oncotarget, $\quad 7, \quad 56447-56455$. http://doi.org/10.18632/oncotarget.10906

OGINO, S., KAWASAKI, T., BRAHMANDAM, M., CANTOR, M., KIRKNER, G. J., SPIEGELMAN, D., MAKRIGIORGOS, G., WEISENBERGER, D., LAIRD, P.W., LODA, M., FUCHS, CH.S. (2006) Precision and Performance Characteristics of Bisulfite Conversion and RealTime PCR (MethyLight) for Quantitative DNA Methylation Analysis. Journal of $\begin{array}{lll}\text { Molecular } & \text { Diagnostics, } & \text { 209-217. }\end{array}$ http://dx.doi.org/10.2353/jmoldx.2006.050135

OLKHOV-MITSEL, E., ZDRAVIC, D., KRON, K., VAN DER KWAST, T., FLESHNER, N., BAPAT, B. (2014). Novel Multiplex MethyLight Protocol for Detection of DNA Methylation in Patient Tissues and Bodily Fluids. Scientific Reports, 4. http://dx.doi.org/10.1038/srep04432

REDSHAW, N., HUGGETT, J. F., TAYLOR, M. S., FOY, C. A. DEVONSHIRE, A. S. (2014). Quantification of epigenetic biomarkers: an evaluation of established and emerging methods for DNA methylation analysis. BMC Genomics, 15, 1174. http://dx.doi.org/10.1186/1471-2164-15-1174

ROGERS, S., BENDICH, A. (1994). Extraction of total cellular DNA from plants, algae and fungi. Plant molecular biology manual, 8(1) http://dx.doi.org/10.1007/978-94-011-0511-8 12

SHEN, L., WATERLAND, R. A. (2007). Methods of DNA methylation analysis. Current Opinion in clinical nutrition and Metabolic Care, 10, 576-581. http://dx.doi.org/10.1097/MCO.0b013e3282bf6f43

SINGER-SAM, J., LE BON, J. M., TANGUAY, R. L., RIGGS, A. D. (1990) A quantitative HpaII-PCR assay to measure methylation of DNA from a small number of cells. Nucleic Acids Research, 18(3), 687. http://dx.doi.org/ 10.1093/nar/18.3.687

SUZUKI, M. M., BIRD, A. (2008). DNA methylation landscapes: provocative insights from epigenomics. Nature Reviews Genetics. 9, 465-476. http://dx.doi.org/10.1038/nrg2341

THIEBAUT, F., HEMERLY, A.S., FERREIRA, P.C. (2019). A Role for Epigenetic Regulation in the Adaptation and Stress Responses of Non-mode $\begin{array}{llll}\text { Plants. Frontiers in Plant } & \text { Science, }\end{array}$ http://dx.doi.org/10.3389/fpls.2019.00246

TRINH, B. N., LONG, T. I., LAIRD, P. W. (2001). DNA methylation analysis by MethyLight technology. Methods, 25, 456-462. http://dx.doi.org/10.1006/meth.2001.1268

YU, M., CARTER, K. T., MAKAR, K. W., VICKERS, K., ULRICH, C. M. SCHOEN, R. E., BRENNER, D., MARKOWITZ, S. D., GRADY, W. M (2015). MethyLight droplet digital PCR for detection and absolute quantification of infrequently methylated alleles. Epigenetics, 10(9), 803-809. http://dx.doi.org/10.1080/15592294.2015.1068490

WEISENBERGER, D.J., CAMPAN, M., LONG, T.I., KIM, M., WOODS, C., FIALA, E., EHRLICH, M., LAIRD, P.W. (2005). Analysis of repetitive element DNA methylation by MethyLight. Nucleic Acids Research, 33(21), 6823-6836. http://dx.doi.org/10.1093/nar/gki987

ZHANG, Z., GAO, J., QIN, C., LIU, L., LIN, H., SHEN, Y., GAO, S., ZHAO, M., DING, H., PAN, G. (2010). A High-Through Technique to Measure DNA Methylation. Genetics and Epigenetics, 3, 5-13. http://dx.doi.org/10.4137/GEG.S5035

ZHOU, J., CAO, J., LU, Z., LIU, H., DENG, D. (2011). A 115-bp MethyLight assay for detection of p16 (CDKN2A) methylation as a diagnostic biomarker in human tissues. BMC Medical Genetics, 12(67). http://dx.doi.org/10.1186/1471 2350-12-67 